Jurnal Administrasi Publik (Public Administration Journal), 10(2) December 2020

ISSN2088-527X (Print) ISSN2548-7787 (Online) DOI: https://doi.org/10.31289/iap.v10i2.3178

Jurnal Administrasi Publik (Public Administration Journal)

Available online http://ojs.uma.ac.id/index.php/iap

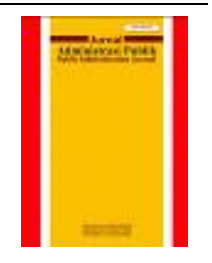

\title{
Alternative Policy on Progressive Tax Rate on Idle Land in the Special Capital Territory of Jakarta
}

\author{
Rizki Nanda Apriani \& Inayati \\ Department of Administration and Tax Policy, Faculty of Administrative Sciences, University \\ of Indonesia
}

Received: December 07, 2019; Reviewed: December 16, 2019; Accepted: July 22, 2020

* Coresponding Email: kinanadika@gmail.com

\begin{abstract}
The objective of this study is to analyze the alternative progressive tax rates on idle land in DKI Jakarta. Researchers used qualitative method. Based on the results of the analysis through data collection carried out using literature studies and in-depth interviews with informants, it can be concluded that with this progressive tax rate policy alternative it is believed that it can suppress effectively and precisely the concentration pattern of land ownership and control as well as speculative behavior towards land and legal entities that hoard the land. These laws and government regulations were inadequate to be applicable to non-agricultural lands or lands with ownership, or use rights. It is due to both of them have not regulated the extent of non-agricultural land, as well as the area of land ownership rights, building use rights, and use rights either for individual or legal entities. The imposition of a progressive tax rate by looking at the length of ownership adopted by South Korean country was also considered capable of being a pretty good way dealing with this idle land problem. The results of study related to the imposition of a progressive tax rate on idle land using the excess scheme or additional collection on the building land tax has been previously imposed.
\end{abstract}

Keywords: Idle Land, Progressive Tax, Property Tax

How to Cite: Apriani, R.N, \& Inayati (2020). Alternative Policy on Progressive Tax Rate on Idle Land in the Special Capital Territory of Jakarta. Jurnal Administrasi Publik (Public Administration Journal). 10(2): 127-137 


\section{INTRODUCTION}

Land is a resource that is limited in availability and has a high social function. The existence of land is an important factor for the Indonesian economy. The most important thing is how investment in the form of land also creates economic activity, especially for a country. The issue of land supply is particularly concern to the government. In big cities, the price of land is increasing, due to the large number of land speculators or brokers in a particular province. The skyrocketing land price is also caused by the society preferring land as an investment tool. The land was bought by people but it was left unused for a long time can be called as idle land.

Table 1. Performance Accountability Report of Government Agencies (LAKIP) of the National Land Agency of the Republic of Indonesia (BPNRI) 2012

\begin{tabular}{llll}
\hline Work & \multicolumn{3}{l}{ Achievements in 2012 } \\
\cline { 2 - 3 } Indicators & Target & $\begin{array}{l}\text { Realizatio } \\
\mathrm{n}\end{array}$ & $\%$ \\
$\begin{array}{l}\text { The } \\
\text { increasing }\end{array}$ & $\begin{array}{l}\text { 459 } \\
\text { number of }\end{array}$ & $\mathbf{2 8 5}$ & 62.0 \\
$\begin{array}{l}\text { location } \\
\text { idle land }\end{array}$ & locations & 9 \\
$\begin{array}{l}\text { determinatio } \\
\text { n decisions }\end{array}$ & & & \\
\hline
\end{tabular}

Source: Quoted from LAKIP BPN-RI 2012

Based on Andi Renald's statement as Secretary of the Directorate General of Control of Spatial Use and Land Control (PPRPT), he explained that the Ministry of Agrarian Affairs and Spatial Planning / Head of the National Land Agency has a database of idle lands that have been collected from 2010 to July 2019 totaling 4,042 fields covering an area of 2,927,809 hectares indicated land displaced.

There are several criteria that can be used to define and categorize idle land as stated in Article 2 of Government Regulation No. 11 of 2010 concerning control and utilization of idle land where it is stated that a land can be categorized as idle land if it includes conditions as below. : 1) The land has already been granted rights by the state which can be in the form of Ownership Rights, Business Use Rights, Building Use Rights, Use Rights and Management Rights, or the basis of control over land status; 2) The land is not cultivated, is also not used or is not used in accordance with the circumstances or the nature and purpose of granting rights or the basis for control.

Local taxes include idle land which more specifically falls into the category of Property Tax. This tax is included in the category of land and / or building tax that is owned, controlled, and / or used or utilized by an individual or entity, other than areas used for plantation, forestry and mining business activities. The tax rate is determined in terms of its nature, which is regressive, flat, and progressive. It is the main instrument in social reengineering through fiscal policy. Careful planning is needed in implementing tax policy instruments, the results can be used as a benchmark for whether the policy is optimal or actually backfires. The risk of implementing this public policy is commensurate with the impact or benefit obtained by the society itself. The existence of idle land causes land prices to be higher since the less land area that can be purchased. This is due to land ownership in a large area and not being worked on by a handful of people which can encourage landowners to be able to empower their land and therefore have a positive impact on the economy.

In 2019, the DKI Jakarta government issued Governor Regulation No. 41 of 2019 concerning Imposition of Rural and Urban Property Taxes to Individual Taxpayers on Building Tax Objects. Described in Governor Regulation No. 41 of 2019, empty land is a stretch of land that is not used or cultivated by the owner and there is no permanent building on it, either in whole or in part. Empty land mentioned in paragraph (2) which is located along a) Jalan $\mathrm{MH}$ Thamrin; b) Jalan Jendral Sudirman; c) Jalan HR Rasuna Said; d) Jalan Jendral Gatot 
Subroto; e) Jalan MT Haryono; Along the five protocol roads in DKI Jakarta, there are still many empty lands that are not useful and have the potential to cause problems for the beauty and order of the city. In the case of Idle Land which is used by the taxpayer as a green open space, then the imposition of PBB-P2 of 50\% (fifty percent) of PBB-P2 owed in the current year. (4) The implementation of the provisions as meant in paragraph (4) obliged to obey the provisions of the regional apparatus which carry out government affairs in the forestry and gardening sectors. The issuance of Governor Regulation No.41 of 2019 is not as if it is without any gaps, the researchers assess that there is another alternative in the form of progressive rates imposed on these idle lands or lands. Given that the regulation only states that only protocol roads will be subject to a tariff of $200 \%$ of the PBB tax rate. An alternative to the progressive tax rate, the imposition of which can be based on the subject and tax object, ownership and function of the land.

\section{RESEARCH METHOD}

This study used a qualitative approach. It is based on the understanding of the qualitative approach from Leedy and Jeanne:

"Qualitative approaches have two things in common. First, they focus on phenomena that occur in natural setting, that is in the "real world" and second, they involve studying those phenomena in all their complexity. (Leedy and Jeanne, 2001).".

Based on the above understanding, the qualitative approach is a research process that focused on phenomena carried out in natural settings and the qualitative approach tried to understand phenomena in more depth with all of their complexity. The qualitative approach was used by researchers to understand the phenomena related to the alternative progressive tax rate policy on idle land and the reasons for the alternative policies that can be implemented. The data collected were obtained from several supporting sources and the research was carried out in a natural setting and the researcher as the main instrument in analyzing the data and used a conceptual framework.

Based on the objectives of the study, the type of study used in this study was descriptive research, because this study was conducted to describe the alternative progressive tax rate policy on idle land and to analyze the advantages and disadvantages of alternatives to implementing the policy. In this study, two techniques were used to collect information and data, namely: (1) The field study in this study used an intense and indepth interview technique. In-depth interviews were conducted with National Land Head, Regional Tax and Retribution Agency (BPRD), notaries and academics and practitioners, and (2) The literature study in this study used literature collection and study techniques such as journals, theses, previous books, articles, government regulations, and laws. The research site used in this study was a location that has taxation authority, in this case the Ministry of Agrarian Affairs and Spatial Planning at Jalan Sisingamangaraja No. 01 Jakarta, and the National Land Agency at Jalan Taman Jati Baru No. 01 Cideng Central Jakarta. In addition, the researchers also conducted research at the notary office of Anriz Nazaruddin Halim, SH on Jalan Kebon Jeruk Raya No. 17A. 
Table 2. Concept Framework

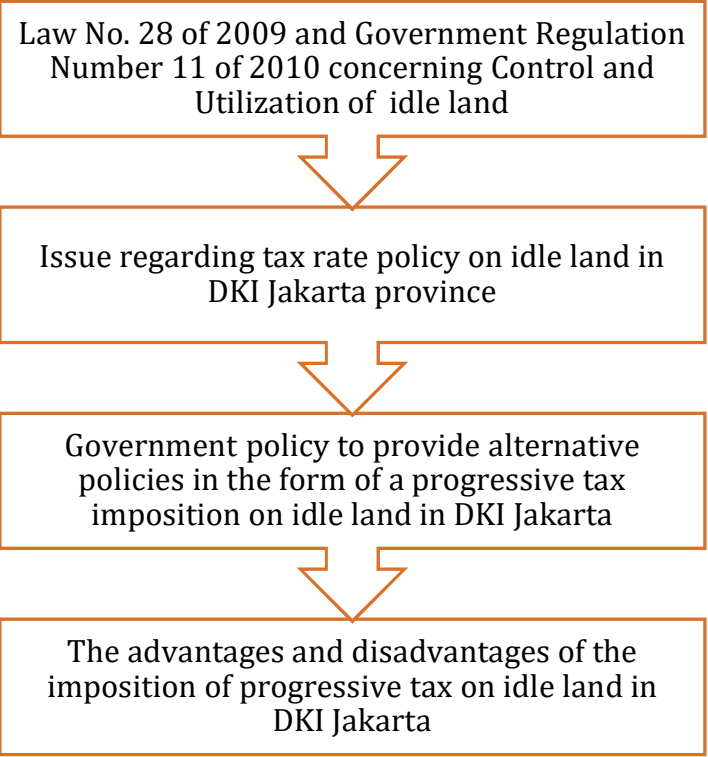

Source: Managed by Researchers

\section{RESULTS AND DISCUSSION Progressive Tax Alternative for Idle Land}

The following describes the results and discussion of alternative progressive tax which is based on the subject and object, ownership and function of the land which can be used for idle land. In Government Regulation No. 36 of 1998 concerning Control and Utilization of Idle Land, in principle, among others, the State controls the land, by compensating it in accordance with a Ministerial Decree and not detrimental to the owner. The emergence of the idle land problem occurs because of the deliberate factor of the holders of land rights or other limited rights granted by the government for not using or utilizing the land. Basically, idle land is state land which has a right to use, but is not used. So it can be concluded that idle land occurs when the holder or who controls the land rights or management rights holders does not carry out activities on the land.

The government in this case can make various intervention efforts through fiscal policy with taxes as one of the instruments in an effort to control land prices because land prices certainly have an impact on one's access to land and buildings. It is necessary to deal with economic liberalization and its impact on the distribution of land tenure.

State revenue will clearly affect the tax itself. In the alternative policy, the progressive tax rate on idle land can be seen based on the subject and object to be imposed, then based on the function of the land itself, and finally from the length of ownership of the vacant or idle land. Talking about alternative progressive taxes that can be imposed on idle land.

First, based on the subject and object of the tax. In the concept of Property Tax, property tax itself is a tax that has a material nature, which means that the tax owed is determined through a different subject or object of land and buildings. Due to the differentiation of Property Tax (PBB) object conditions, the PBB-P2 tax subject certainly has a different ability to pay which means that the condition of the tax subject does not determine the amount of tax as stated by Sidik (2000).

In the phenomenon of idle land, which is stated in Governor Regulation No. 41 of 2019 article (2) regarding the imposition of PBB-P2 on individual taxpayers for building tax objects in the form of houses for the tax in the year of 2019 in accordance with the provisions of PBBP2 for the tax in 2018. In addition, in article 3 it is stated as what article 2 stated that it is exception to tax object tax in the form of idle land.

Where the tax object is in the form of land that does not see who the owner is, but it can be imposed if it owned the land, and used the land, one of them is taxed, and only sees whether the land object has been included as a tax object or not, which is quoted from interview with Andri Maulidi Rijal as Head of the Service Unit, unit of the Extension Services and Information Services at the Regional Tax and Retribution Agency.

The Indonesian Taxation Law regulates the collection of taxes on land and / or buildings with three different types of taxes, namely 1) Rural and Urban Land and Building Tax (PBB-P2) which has a base of wealth ownership or which is known in various countries as tax on property (PBB-P2); Fees for the acquisition of land and building rights 
(BPHTB) on the transfer of ownership / rights to property, and 3) Tax on income (PPh). Specifically for PBB-P2 and BPHTB, since being devolated in 2014 through the PDRD Law No. 28 of 2009, which was previously a Central Tax, has been converted into Regional Tax. The objects of PBB-P2 are land and / or buildings that are owned, controlled, and / or utilized by private persons or entities, except for areas used for plantation business activities; forestry; and mining, as regulated in Law No. 28 of 2009 concerning Regional Taxes and Regional Levies.

However, the weakness of this progressive tax is the increase in Sales Value of Taxable Object which is directly significant. Where there is a nominal transition that is not normal, but now Properti Tax is being returned to each region to be managed. Where it is stated that the weakness of this progressive tax rate is in the rate transition. Where to formulate this alternative policy there must be an analysis, how progressive it is, and also not forgetting the shape and how the layer of progressive tax imposition on idle land.

Complementing the current taxation policy for land and/or buildings, the government was considering imposing a final, progressive tax rate on land sales transactions on unutilized assets tax and tax on land and / or buildings with a progressive tax instrument. This tax was imposed on profits arising from the sale of land. The progressive tax instrument was expected to be a disincentive for speculators and land and / or building investors. Meanwhile, this policy was intended as a form of affirmative policy with government funding sources in order to overcome and reduce socio-economic inequality.

Governor Regulation 41 of 2019, the government used significant rates on these untapped land. The Governor of DKI Jakarta, Anies Rasyid Baswedan issued a policy in the form of raising taxes on vacant land along the protocol road. The decision came into effect on January 1, 2019. The increase in tax on vacant land on the capital city protocol road is contained in the Governor Regulation (Pergub) Number 41 of 2019 concerning Imposition of
Rural and Urban Property Taxes to Individual Taxpayers on Building Tax Objects in the Form of Houses for the 2019 Tax Year, especially Article 3.

The idle lands affected by the tax hike were along Jalan MH Thamrin, Jalan Jenderal Sudirman, Jalan HR Rasuna Said, Jalan Jenderal Gatot Subroto, and Jalan MT Haryono. This policy makes land voters, who are usually managed by the private sector, later provide green open space (RTH). If the land functions as RTH and can be accessed by the public, the DKI Provincial Government will provide a tax discount of up to 50 percent. If you do not provide green space, the land tax burden will increase to 200 percent from the previous rate.

However, looking at the opposite side of the Governor's Regulation, the government was trying to implement the Green Open Space (RTH) regulation implemented by Singapore. Then it was feared that it can change the function and regional spatial plan (RTRW) if the making of green open space (RTH) was carried out. The regulation by doubling taxes was still inaccurate. It is since the vacant land that had not been built could be related to constraints from the licensing sector, costs, or the commercial sector.

However, the local government was still carrying out a fiscal cadaster, which was collecting data on land and occupancy issues throughout Jakarta. From there, we will have data on how many vacant lots on the main roads in Jakarta (https://tirto.id/dm5J, 2019)

One of the considerations of the alternative policy formulation was in its implementation, it was found that among other things, the amount of tax paid on the sale/purchase transaction of land and/or buildings was lower than the potential tax based on the actual transaction value (fair value). Apart from indications of dishonesty, it cannot be denied that there is a difference of Sales Value Taxable Object between one property and another within an area, even within the same area. The difference in the intra-regional of Sales Value Taxable Object was influenced by public facilities. Therefore, the government had proposed a change in the 
tax base from Sales Value Taxable Object (wealth base) to capital gains base.

But the progressive tax did not apply easily, it needs adequate criteria to determine land as unproductive or to determine a behavior on land as speculative. If it was not carried out carefully, these policies would not be effective in solving unproductive land problems and speculative behavior. In fact, at a certain point, the policy had the potential to be counterproductive to a number of land policies, which regulated the elimination of idle land rights.

Regarding the tax object itself, it will obviously had an effect on tax revenue, because the price of vacant land and land with existing buildings was clearly different, where the difference was on the sales side. Land that already had a building above was one of the contributors to the regional tax itself, where there was a Sales Value Taxable Object of land and a Sales Value Taxable Object of building. For example, if the land was empty and there was no buildings standing on it, it will result in less than optimal tax revenue itself.

Second, based on Ownership, Equitable land ownership tends to be a government issue in several developing countries. The increase in people owning houses by $82.8 \%$ from 2010 (by $72 \%$ ) was not yet an indicator of increasing housing fulfillment for the society. It was since property prices such as houses or apartments were not proportional to the increase in the average income or salary of the society. Each year the price of housing increases by 20-30 percent, while the income or salary of employees only increases by about 10 to 15 percent per year. There were still groups of people who found the difficulty in having house due to the incomparable increase in land and property prices, such as houses or apartments, with an increase in income or salary for office employees.

The government collected the tax policies on land, among others, through Rural and Urban Property Taxes (PBB-P2) on ownership. This tax was initially collected by the central government and then devolated to local governments through Law Number 28 of 2009 concerning Regional Taxes and Regional Levies (PDRD). The PBB-P2 devolution policy has the objectives, among others, to strengthen the local taxing power of regencies / cities as the spearhead in providing services to the society.

It is analogized that using the land or leaving it idle for a long time is an absolute right for the land owner. However, as time goes by, more and more speculators have invested in vacant land, which causes the price of land to rise. If the price of vacant land goes up uncontrollably, of course the people who do not have much money will be increasingly unable to buy it. In other words, land speculators have become a major influence after the government, in the system and access to housing ownership for the society and millennials. Speculators also control land that is integrated with the government's infrastructure development plans, causing the difficulties in urban spatial planning and land acquisition processes in infrastructure development. With the imbalance between housing needs and people's purchasing power, the role of the government by intervening indirectly in the making of regulations that can intervene indirectly in these conditions is needed. By making policies that can balance residential needs and people's purchasing power, it is expected that it will be a win-win solution in solving problems of increasing property prices such as land, houses or apartments and optimizing sustainable development and of course benefiting all parties involved.

There were restrictions on the amount of speculative land purchases which can hinder the development of infrastructure and property in Indonesia itself. The negative impact was the impact on higher prices which result from speculative purchases, as well as reduced housing development that is affordable for the poor and middle to lower class. By imposing a higher sales tax on land sold within a specified (short) period of time to prevent people from buying and selling land for a short period of time.

The challenge of this policy discourse was the government needs a strong database of 
data on when the transfer or timing of land ownership and acquisition price of land began, which until now is still relatively difficult to obtain considering that the data are owned by the seller and the buyer. In a slightly different model, the Motor Vehicle Tax (PKB) policy has accommodated this concept in the form of a progressive Final Income Tax modified from the Final Income Tax Article 4 paragraph (2). The current owner / subject of motor vehicle tax may be the subject to progressive tax for second, third, fourth vehicle ownership and so on, as seen from data on motor vehicles registered under the same name and/or address. The PBB-P2 progressive tax policy can be collected periodically.

The scheme which was used namely First, under the progressive tax rate scheme on land, landowners paid higher taxes for their second land location, even higher taxes on the third and so on before a certain period such as five years. Business bases, such as uninhabited or idle land, were taxed to higher rates. It also applied to land which is the object of speculation. Second, the profit on the sale of land was taxed to capital gain taxed where the positive difference between the selling price and the acquisition price will be taxed. Third, non-productive land or land that was idle or without a clear development plan was taxed for idle land. Theoretically, the new policy will reduce land prices and finally provide better access to housing. Not infrequently, the three of them occured simultaneously on the same plot of land. Moreover, as explained earlier, the government's own policies could be considered lame from the start.

In the initial study, it was possible to make an alternative additional tax on PBB-P2 (surcharge) on the basis of the taxation in the form of sale value taxable object with a certain rate and under the provisions which was separated from the current Property Tax Law.

Therefore, although some land policies were not sufficient to be widely applied to these land issues, the use of land law instruments that regulate ownership boundaries was believed to be able to suppress effectively the concentration of land ownership, including inhibiting land speculation. Land policy reforms coupled with law enforcement were needed so that they were able to reduce effectively the number of unproductive landed lands, as well as the concentration of land ownership and control in high areas. Meanwhile, taxation policy on land in this case can be a complementary instrument for land policy, either as an incentive or a disincentive for land management. Of course, along with that a number of administrative updates were needed, both in the land and tax fields.

An example is the city of Seoul which also implemented this system when the price of land in Seoul increased due to speculative action which caused land prices increase by up to $136 \%$, where the availability of land was low even dwindles. This situation motivated the government to be able to impose a tax on vacant land, it was done to reduce speculation and encourage development to run. The Seoul government applied a tax of $5 \% \%$ or higher than the normal rate imposed, which was $2 \%$. This higher tax rate which, if left unchecked, became $7 \%$ for three years of idle and an idle period of five years was taxed to $8 \%$. Moreover, the government would confiscate the land if the tax imposed was not paid.

If you take the example in China, land speculation such it, raises many problems which in some countries have good reasons to intervene. According to the "Disposal Measure for Idle Land" made by China, the time for land development is limited to 2 years. If this is exceeded, the government will return the land use rights back to the state without any compensation for the developer. With this regulation, it was expected that it would further reduce the inefficiency of neglected or unused land, which results in a lack of land that can be used for more useful things.

As it is, the existence of an alternative to the imposition of a progressive tax rate on idle land will clearly affect speculators as well as leading property developers owning hundreds to thousands of hectares of idle land to be used for property development investment. An example is Sentul City, a company from Bogor 
with the issuer code BKSL has a land bank of 14.3 thousand hectares. Meanwhile, Bumi Serpong Damai (BSDE) and the Jababeka Industrial Estate (KIJA) have 4.1 and 3.2 thousands landbank, respectively, spread across several regions.

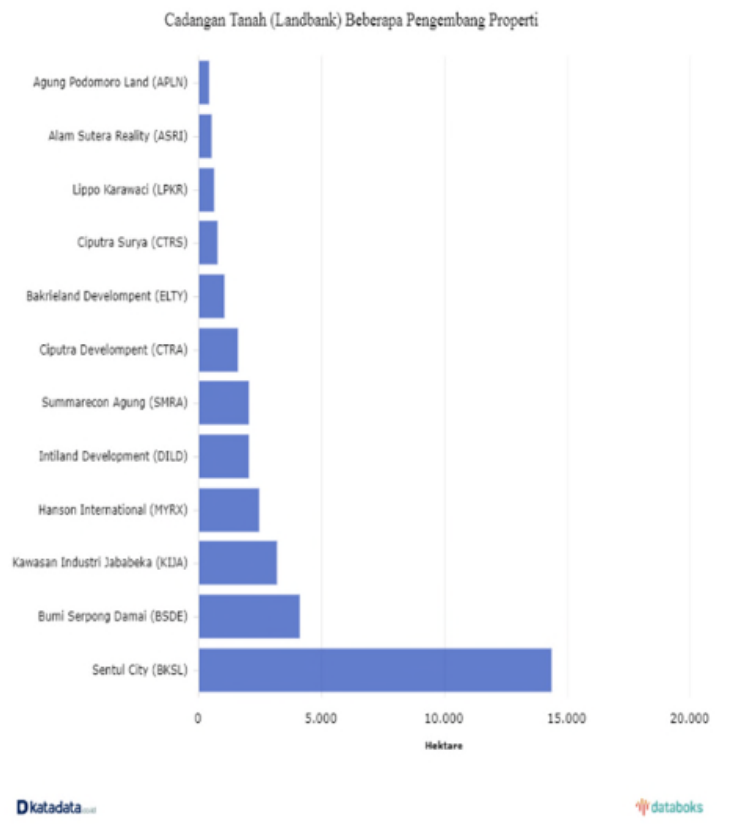

Graph 1. Land Bank of Several Property Developers Source: Indonesia Stock Exchange (IDX), PT, Grahanusa Mediatama, PT, 2017

The precise definition of idle land is a system to ensure that the landowners report the actual selling price, and access for the Directorate General of Taxes to the land ownership database are some of the factors needed to achieve good regulation, real-time and actual ownership time data in determining the amount of progressive tax to be imposed. If the government succeed achieve this, taxes could contribute to state revenues to support the massive infrastructure development projects being promoted by President Joko Widodo's administration, but it would be a pleasant surprise if idle land taxes could suppress speculative land purchases to aid affordability. housing prices in Indonesia.

On the other hand, the imposition of progressive taxes on vacant or idle land has a good impact in terms of the subject of taxation which will certainly provide a deterrent effect in hoarding or investing but not being utilized.

In comparison there were drawbacks, namely, problematic land valuations and chaotic land owning administration, preventing countries from collecting more revenue from land taxes. This administrative problem probably occurred in Indonesia as well. Currently, based on Indonesian tax law, an income tax of 2.5 percent applies to the gross selling price of land, but it is no secret that Indonesian landowners can easily manipulate the price of land sold to evade tax. People can also circumvent progressive tax rates by transferring land ownership between family members or business associates. The fact that the Directorate General of Taxes did not have access to the land ownership database managed by the National Land Agency exacerbates this problem. The weak monitoring becomes another problem.

The third is based on the Land Function. The important factor for the economy of the Indonesian people is the existence of the land itself, the most important thing is the investment can create economic activity for a country.

Apart from being an important factor for the economy, land also occupies an important position in various disciplinary studies such as social, political, legal and cultural sciences. Land is associated with the existence of a country and is a place where a culture emerges. Various historical events of war, such as Indonesian independence, cannot be separated from human activities that continuously fight over land.

Land has beneficial values that have an impact on human life, including: Land is a natural asset that provides space for other assets such as houses or other property that require space, Land gives life and becomes social space, Land can provide infrastructure space for various human needs such as roads, water and sanitation. Land has high economic value, can be bought and sold, can also be passed on to the family as a hereditary heritage which has historical and economic value as well as depending on the position and 
economic location of the land. With this high economic value, land can also be used as loan collateral. Then the land can be a source of increased income for the owner. Through land use, the owner can get profit by hiring the land.

Based on some of the benefits and functions above, it can be concluded that land is not used as a means of investment and a source of wealth for humans, but can be used to support people's lives in terms of infrastructure, guarantor of society needs or for other social activities.

In terms of the function, idle land could interfere with the productivity of the society, because the land was not used so that it was not productive. Where in accordance with the Governor Regulation No. 41 of 2019, if using in the case of Idle Land which was used by the taxpayer as a green open space (RTH) which can be used by the general public free of charge in accordance with the provisions of laws and regulations, the imposition of PBB-P2 of 50\% ( fifty percent) of PBB-P2 owed in the current year.

It can lead to the growth of slum areas which can reduce the aesthetics of the city and can reduce the efficiency of land use and can cause other social problems. However, the progressive tax was not easy to be applied, because of the need for adequate criteria to determine land as unproductive or to determine behavior on land as speculative. If it was not carried out carefully, these policies would not be effective in solving unproductive land problems and speculative behavior. In fact, at a certain point, the policy had the potential to be counterproductive to a number of land policies, which regulate the elimination of idle land rights.

\section{Advantages and Weaknesses of Progressive Tax Imposition on Idle Land}

The advantages and disadvantages of one of the alternatives used were the alternative to the imposition of progressive tax on idle land. First, the advantage of the progressive tax alternative on idle land is in terms of the subject of taxation, it would certainly provide a wary effect in hoarding or investing but not being utilized. Listed in Governor Regulation No. 41 of 2019 article (3), the emergence of many green open spaces could be utilized by the general public free of charge in accordance with the provisions of the laws and regulations as a result of the governor's regulation. Judging from the social function itself, it could be achieved, then from the economic function it can bring job field. Furthermore, the most important thing was to choose soil fertility (Article 15). However the most clear and most important thing is a wary effect so that the rights given was fair.

The weakness of this alternative itself was it can transfer ownership. Land owners can also circumvent progressive tax rates by transferring land ownership between family members or business associates. The fact that the Directorate General of Taxes does not have access to the land ownership database managed by the National Land Agency exacerbates this problem. Weak monitoring itself is another problem.

\section{CONCLUSION}

Based on the research, the alternative policies for the imposition of progressive tax rates on idle land in DKI Jakarta met the indicators of progressiveness of progressive tax imposition on idle land which can be seen based on the subject and object to be imposed, then based on the function of the land itself, and finally seen from the length of ownership of the vacant or idle land. Whereas the tax object is in the form of land which did not see the subject of the owner of the land, but it can be imposed if it owned the land, and one of the ways to use and utilize the land is subject to tax, and only to see whether the land object has been included as a tax object or not. Then based on land ownership, landowners will pay higher taxes for the location of their second land, higher taxes on the third and so on before a certain period such as five years. In addition, based on the function of land, it can be concluded that land was not only 
used as a mean of investment and a source of wealth for humans, but could be used to support people's lives in terms of infrastructure, for example used for public facilities and as a guarantor for society needs or for other social activities.

\section{BIBLIOGRAPHY}

American Institute of Certified Public Accountants, (2001). Guiding Principles of Good Tax Policy: A Framework for Evaluating Tax Proposals. New York : American Institute of Certified Public Accountants, Inc

Ardiwijaya V.S., Sumardi T,P., Suganda E., Temenggung Y,A. (2015). Rejuvenating idle land to sustainable urban form: case study of Bandung metropolitan area, Indonesia. Procedia Enviromental Sciences. $28,176-184$

Ariany, N. (2010). Analisis Progresivitas Pajak Bumi dan Bangunan (PBB) Bagi Wajib Pajak Orang Pribadi di Jakarta Selatan Serta Hubungannya Dengan Ketidakmampuan Membayar PBB. Universitas Indonesia. Depok.

Banzhaf H S., Lavery Nathan. (2010). Can the land tax help curb urban sprawl? Evidence from growth patterns in Pennsylvania. Journal of Urban Economics. 67, 169-179.

Bird, Richard M. dan Enid Slack. 2012. Land and property Taxation: A review. http://www1.worldbank.org/publicsector/dec entralization/June2003Seminar/LandProperty Taxation.pdf

Congressional Policy and Budget Research Department House of Representatives. Idle Land Tax: Implementation Issues and Challenges CPBRD Policy Brief.

Coulson Edward, N., Li Herman. (2010). The effect of risk on the effect of a land tax: A simulation. Regional Science and Urban Economics. 40, 530-537

Creswell, J. (2013). Research Design (Pendekatan Kualitatif, Kuantitatif, dan Mixed). Yogyakarta: Pusaka Pelajar.

Darwin, (2013), Pajak Bumi dan Bangunan Dalam Tataran Praktis Edisi 2, Jakarta, Penerbit Wacana Media.

Diana Sari. (2013). Konsep Dasar Perpajakan. Refika Aditama. Bandung.

Dunn, W, N. (2003). Pengantar Analisis Kebijakan Publik: Public Policy Analysis. Yogyakarta: Gadjah Mada University Press

Emzir. (2012). Metodologi Penelitian Kualitatif: Analisis Data. Jakarta: Rajawali Pers.

Fisher, M. Ernest. (1958). Economic Aspect of Urban Land Use Patterns. The Journal of Industrial Economics, June, Vol. 6, S. 198-208.

Governor Regulation No. 41 of 2019 concerning Imposition of Rural and Urban Property Taxes to Individual Taxpayers on Building
Tax Objects in the Form of Houses for the 2019 Fiscal Year

Government Regulation Number 11 of 2010 concerning Control and utilization of idle land.

Islamy, M, I. (2009). Perumusan Kebijaksanaan Negara. Jakarta: Bumi Aksara

Kalkuhl M., Milan F. B., Schwerhoff G., Jakob M., Hahnen M., Creutzig F. (2018). Can land taxes foster sustainable development? An assessment of fiscal, distributional and implementation issues. Land Use Policy. 78, 338-352.

Lasmana, E. (1992). Sistem Perpajakan di Indonesia, Jakarta: Prima Kampus Grafika.

Law Number 28 of 2007 concerning the Third Amendment to Law Number 6 of 1983 concerning KUP.

Lestari, D. (2015, November 8). Dipetik February 13, 2017, dari Kenapa Anda Sulit Beli Rumah Sebelum Usia 30? Ini Alasannya Beberapa faktor berikut harus Anda perhatikan: http://bisnis.news.viva.co.id/news/read/6966 93-kenapa-anda-sulit-beli-rumah-sebelumusia30-ini-alasannya.

Montefrio M., Dressler W. (2016). The Green Economy and Constructions of the "Idle" and "Unproductive" Uplands in the Philippines. World Development. Vol .79, 114-126.

Neuman, W. L. (2007). Basics of Social Research, Qualitative and Quantitative Approaches 2nd ed. Boston: Pearson Education.

Nurmantu, S. (2003). Dasar-Dasar Perpajakan. Jakarta: Universitas Terbuka.

Nurmantu, S. (2005). Pengantar Perpajakan Edisi 3. Jakarta: Granit

O'Sullivan, A. T. (1995). Property Taxes and Tax Revolts: The Legacy of Proposition 13. Cambridge: Cambridge University Press

Pantya J., Kovacs J., Kogler C., Kirchler E. (2016). Work performance and tax compliance in flat and proggresive tax system. Journal of Economic Psychology. 56, 262-273.

Pitoko, R. A. (2016, August 25). (H. Alexander, Penyunt.) Dipetik February 1, 2017, dari Catatan Hapernas 2016, 82,8 Persen Kepemilikan Rumah Bukan Indikator Kesuksesan: http://properti.kompas.com/read/2016/08/25 L100000521/Catatan.Hapernas.2016.82.8.Pers en.Kepemilikan.Rumah.Bukan.Indikator.Kesuks esan

Ramadhan, B. (2019, April 26). Dipetik Februari 1, 2017, dari Nasional Republika, Aturan PBB Gratis Ada Syaratnya: https://nasional.republika.co.id/berita/nasi onal/iabodetabeknasional/pqir22330/aturan-pbb-gratis-adasyaratnya 
Jurnal Administrasi Publik (Public Administration Journal), 10 (2) December 2020: 127-137

Sidik. (2000). Model Penilaian Properti Berbagai Penggunaan Tanah di Indonesia. Jakarta: Yayasan Bina Ummat Sejahtera. 